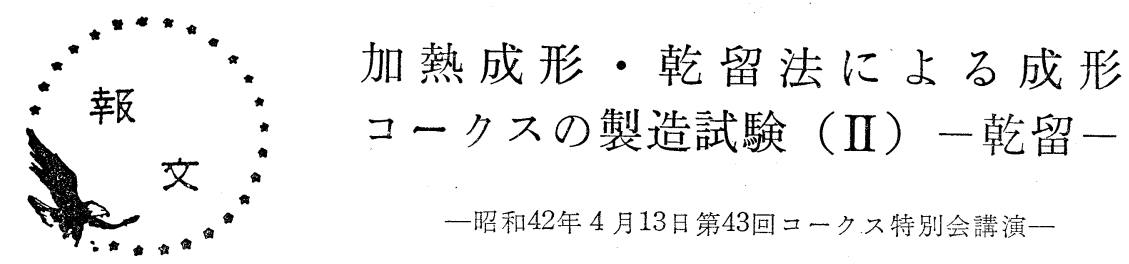

資源技術試験所 吉田 雄次・熊井順二郎

山口潔・白石 稔

戸田 雄三・丸山 勝久

\section{I.まえがき}

非粘結炭または弱粘結炭を主原料として，これを予 備加熱して成形し, さらに乾留して無煙然料やコーク スを製造する，いわ沛る加熱成形乾留法の研究が各国 で行なわれつつあり, 当所においても国内炭活用の見 地から国内炭から治金用コークスを製造する方法の一 つとして研究を行なつてきた。すでに実験室試験か ら, さらに処理量約 $150 \mathrm{~kg} / \mathrm{hr}$ の一連の中間試験装置 を設けて試験を実施した。

実験室におるる試験結果および中間装置による前段 の加熱成形炭の製造までについての結果は，すでに昨 年の本誌 ${ }^{1)}$ その他 ${ }^{2}$ で詳細に発表されている。

すなわち, 本コークス製造法は, 強粘結炭を使用し ないこと，採算の悪化した副産物の回収を行なわない こと、コークス化時間を大幅に短縮すること、コーク ス粒度の均一なものが得られること，作業が連続式で 自動化が容易であること，という一連の条件を満足さ せる方法として開発が企だてられたものである。特に コークス化時間については現行コークス炉が10数時間 を要するのに比べて, 本法で法加熱成形に要する数分 を含めてコークス化にわずか $2 \sim 3$ 時間を要するのみ である。これは成形のための加熱 (約 $450^{\circ} \mathrm{C}$ ) 方流動 法によつてきわめて短時間に達せられること, 乾留炉 に入る加熱成形炭が中心まですでに均一に加熱されて いるのでその後の乾留において，亀裂の原因となる成 形炭内の温度勾配が小さくてすみ，したがつて比較的 急速な加熱が可能なこと，などによるものでまたピ ッチを使用していないために軟化や変形を起す心配が 少ないなど多くの利点がある。

今回は前報の成形炭の製造試験結果に続いて, 後段 の乾留試験についての報告であるが，前報での流動加 熱炉についてその後改造された点と，ともに実験室に おける乾留試験, 中間装置で作られた加熱成形炭の電
気炉乾留試験および中間装置による連続乾留試験など の結果について述べる。

\section{II . 流動加熱炉の改造}

流動炉の構造については前回報告したが，その一部 をつぎのように改造した。

改造前のレトルト内部には流動加熱中に粉炭の団塊 化またはレトルト壁への附着を防止するために翼のつ いた攪找機が設けられ，これが一定速度で回転される 構造になつていた。しかし回分試験をある時間継続す ると、レトルト最下部およびレトルト一成形機ホッパ 一間の粉炭シュート管内で加熱粉炭の棚吊り現象が生 じ運転に支障をきたす事態がしばしば発生したため Fig. 1 のように改造した。すなわちレトルト内壁へ の附着は認められないので覺抖棒についている翼を全 部取除き，攪拌棒が加熱粉シュート部分を上下できる

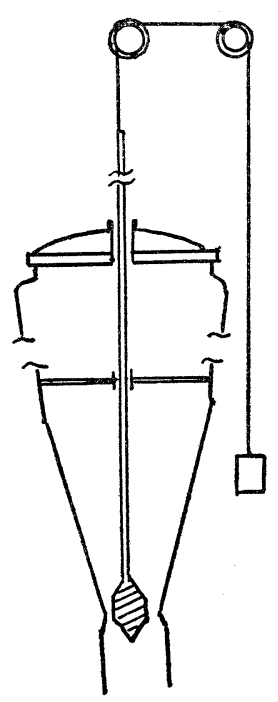

Fig. 1 Detail of retort modified 
ようにし，さらに棒の先端部を太く（110 mm $\dot{\rho} \times 100$ $\mathrm{mm})$ して最先端は鋭角とした。これはレトルト絞り 部の断面積を小さくし，ガス流速を上げて流動中の大 粒の落下を防ぐためと, 棚吊り層の破壊を効果的にす る目的でつけたものである。

流動加熱中には先端が図に示すような位置にくるよ らにするが，懸垂棒のふらつきをなくするためレトル トの約中間位置に支えを設けた。そして加熱粉炭を排 出する際には眯垂棒を上下に動かすようにした。

以上のように改造した後は, 加熱粉炭の排出がスム ーズになり, 長時間連続的な運転を行なつても団塊化 および棚吊による障害は全く起らず, 非常に順調に試 験を続けらるようになつた。

\section{1. 改造後の試験成績}

改造前においては加熱粉炭の排出にさいして障害が 起り易かつたためむあつて，特に高温側 $\left(460^{\circ} \mathrm{C}\right.$ 以上) の実験回数が若干不足であつた。そのため前報にやや 不備な点があつたのでその訂正と補足をかねて, 改造 後の試験結果を概括的に報告する。

（1）流動炉レトルト内の攪拌機の改造によつて, 熱可塑性が可なり大きな原料粉であつても加熱粉の排 出は支障なくでき, 長時間の連続的試験が可能となつ た。

（2）前報において成形炭強度の温度依存性につい て, 加熱粉炭揮発分が $30 \sim 35 \%$ (加熱温度約 $450^{\circ} \mathrm{C}$ ) で最良の成形性が得られると判断したが, 改造後の試 験の結果は，Fig. 2 のようになつた。眓中の各点は 太平洋および奔別炭に夕張炭をそれぞれ $20 \% ， 30 \%$ お

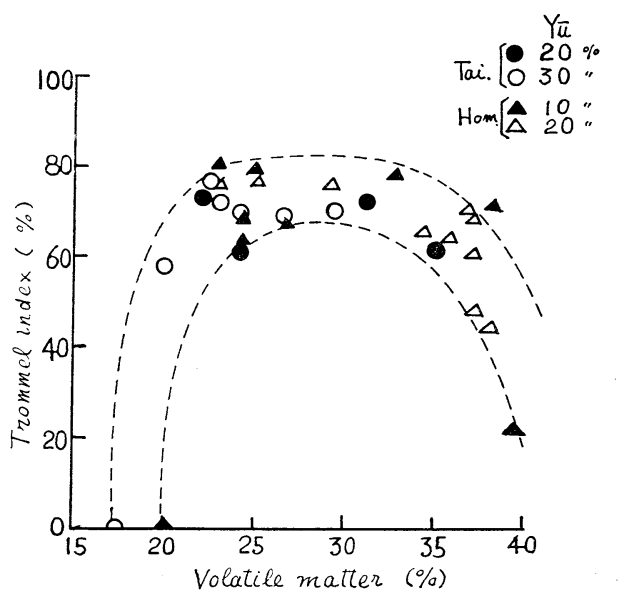

Fig. 2 Relation between volatile matter and Trommel index of green briquettes
よび10\%，20\%配合したものである。眓から明らかな ように，トロンメル強度 $80 \%$ 前後の成形炭が得られる 加熱炭揮発分の範囲が，低揮発分側に拉大され $22 \%$ 近 辺まで減少させても，ハンドリングには十分耐えうる ものが製造できることが明らかとなつた。ただし約 22\% (約 480\%) を越えると成形性は急激に低下寸る。

（3）改造により製品の均一性が向上したため, 試 験結果のバラッキが小さくなつた。

\section{III. 実験室装置による乾留試験}

加熱成形炭を乾留してコークスとする場合, 生成コ 一クスの強度を支配する主なる因子としては，1）成 形炭の残留揮発分（すなわち成形前の流動加熱温度お よび時間)，2）成形圧力，3）成形炭温度（乾留炉装 大温度)，4）乾留加熱速度などが大きなものとして考 えられるので,まず実験室装置によりこれらの各因子 による影響について検討した。

1. 実験方法および条件

原料粉炭 (約 $1.5 \mathrm{~mm}$ 以下) の流動加熱一成形用実験 室装置は前報と同一である。すなわち流動筒径 $50 \mathrm{~mm}$ $\phi$, 毎回 $50 \mathrm{~g}$ を筒頂から投入し, 予熱空気で流動しつ つ加熱, 約 $360^{\circ} \mathrm{C}$ の成形金型に投入して油圧式プラン ジャーで $30 \mathrm{~mm} \phi$ のブリケットに成形する。

成形炭の乾留は装入炉温を $500^{\circ} \mathrm{C}$ と, 特に説明の ない場合の成形炭の装入は, 成形後直ちに装入する, いわゆる熱閒装入法で行ない，最終温度は $800^{\circ} \mathrm{C}$ とし た。乾留装置には能率を高めるためドーナッツ形の小 型回転移床式乾留炉を試作して用いた。(回転速度で 加熱率は変えうる)。コークス強度は耐圧強度を測定 して比較検討した。

\section{2. 実験結果および考察}

（1）成形炭揮発分とコークス強度

まず流動加熱温度の影響をみるため, 各種の温度で 加熱成形し, その成形炭残留揮発分と乾留コークス強 度（耐圧強度）との関係を検討した。この際の実験条 件はつぎのとおりである。

流動加熱温度 : $400 \sim 520^{\circ} \mathrm{C}$, 成形圧力 : $150 \mathrm{~kg} /$ $\mathrm{cm}^{2}$, 乾留加熱速度 : $2.5^{\circ} \mathrm{C} / \mathrm{min}$, 試料: 太平洋

炭および奔別炭に夕張炭を 0 35\% 配合。

その結果を Fig. 3 に示す。図から明らかなように， コークス強度は成形炭揮発分の減少にしたがつて上昇 し，24 27\%（加熱温度約 $460 \sim 470^{\circ} \mathrm{C}$ ）でいずれも強 度が最大となつて急激に下降し，18\%前後で零となる 傾向を示す。すなわちコークス化にさいして最も適し た成形炭の残留揮発分(加熱温度)があることを示す。

なお揮発分と加熱温度との関係は $400 \sim 520^{\circ} \mathrm{C}$ 間で 


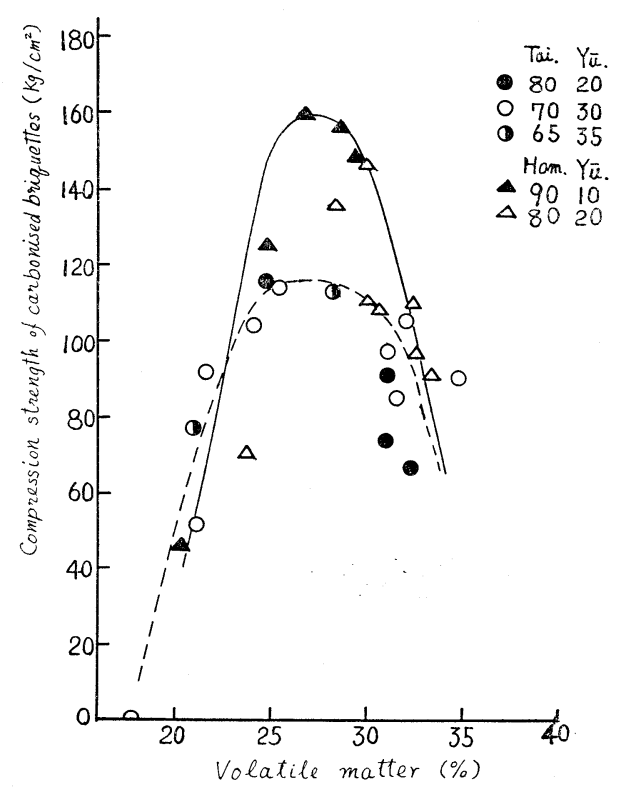

Fig. 3 Relation between volatile matter of green briquettes and compression strength of cabonised briquettes

は直線的関係にあり，y=579.2-4.33x にしたがうこ とが認められた。ただし揮発分 $x$ は無水べースであ る。

（2）成形圧力の影響

成形圧力の影響について，成形および乾留条件を(1) と同じくして検討した。その結果を太平洋炭に夕張炭 20 30\% 配合したさいの結果で示すと Fig. 4 のよう になる。

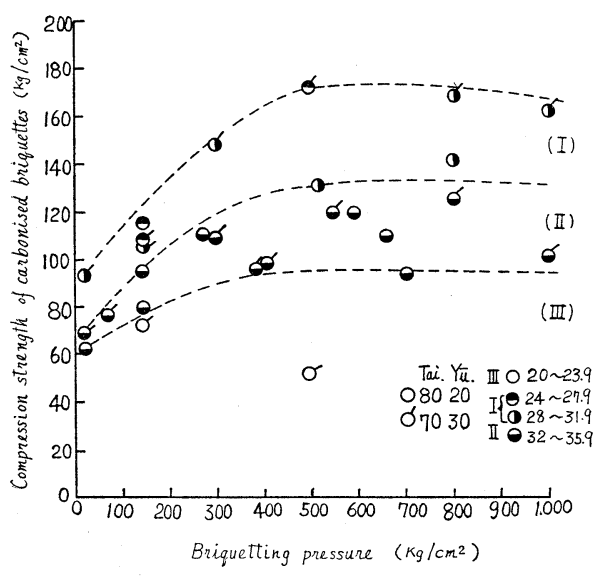

Fig. 4 Relation between briquetting pressure and compression strength of carbonised briqruettes
図から，成形圧力が大きいほどコークス強度も上昇 するが, 約 $300 \mathrm{~kg} / \mathrm{cm}^{2}$ に達すると上昇率は低下し 500 $\mathrm{kg} / \mathrm{cm}^{2}$ でほぼ平衡状態となる。この傾向は前報の成 形炭の成形圧力と成形炭強度との関係の場合の傾向と 同様である。さらにこれを揮発分で大体 3 つに分し てみると (図中鎖線) 図示のごとくきれいに分割でき, Fig. 3 の実験結果からも想定されたように，(1) に 属するもの, 寸なわち成形炭揮発分 $24 \sim 32 \%$ のもの の強度がいずれも高くなつている。そして揮発分が20 \%前後まで減少すると成形圧を増しても効果はなくな る。また同図から夕張炭配合割合による差異も認めら れ, 太平洋炭の場合は $20 \%$ より $30 \%$ 配合が強度の大き いものが得られる。

\section{（3）成形炭装入温度の影響}

熱間成形法によつて得られる成形炭の乾留にさいし て, 乾留炉装入時における成形炭の温度がコークス強 度に非常に影響するであろらということは成形物特性 からも容易に推定される。そこで成形後一旦室温まで 冷却した後装入したもの（冷却装入）と，成形後直ち に装入した（熱間装入）場合，どの程度相違するもの か比較してみた。その結果を Fig. 5 に示す。すなわ ち熱間装入によるコークス強度は冷却装入の場合の約 2 倍の強度を示しており，装入時の成形炭温度がコー クス強度に顕著に影響し，熱間装入による効果の大き いことが認められる。なお一旦冷却したものはいかな

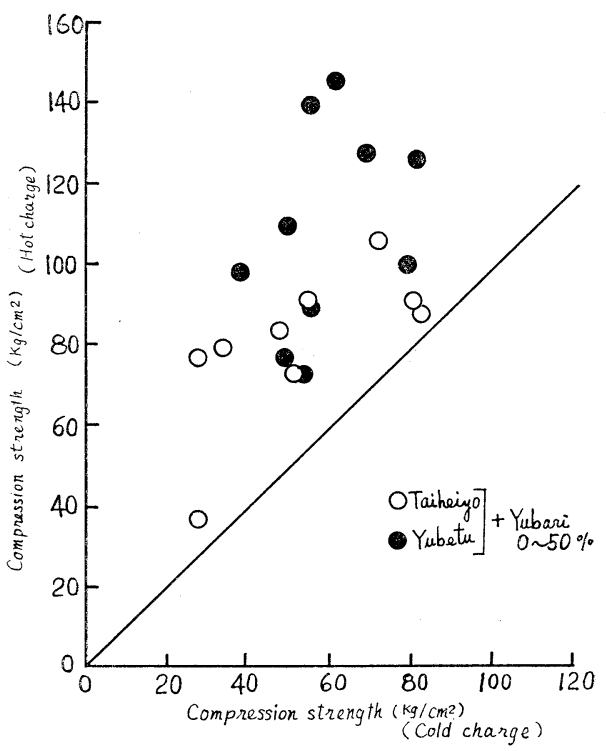

Fig. 5 Effects of hot charging and cold charging on compression strength of carbonised briquettes 
る乾留条件によつて熱間装入コークス強度に匹敵す るもの淂られない。

この結果から，本法に関する一連の工程において， 成形から乾留工程に連絡する閒の成形炭の処理には, 雾囲気および時間に留意することが必要で, 良好なコ 一クスをうるためには, 成形炭の温度降下は極力避け ることが必要である。

（4）乾留加熱速度の影響

乾留の加熱速度に上る影響は, 炭種, 残留揮発分 （流動加熱温度）および圧縮密度などによつて，それ ぞれ異なつてくる。Fig. 6 は太平洋宸およで奔別炭 に夕張炭を $30 \%$ および10\%配合し, 加熱温度 $470{ }^{\circ} \mathrm{C}$, 成形圧力 $300 \mathrm{~kg} / \mathrm{cm}^{2}$ で成形を行ない, 乾留加熱速度 を $2.5 \sim 15^{\circ} \mathrm{C} / \mathrm{min}$ 闆で種々変えたさいのコークス耐 圧強度の変化を示したものである。

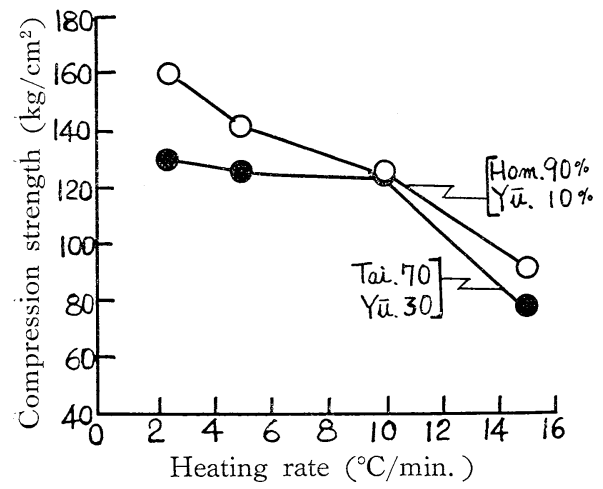

Fig. 6 Effect of heating rate on compression strength of carbonised bripuettes

強度は加熱速度が大きいほど低下するといら常識的 な傾向を示しているが，ただ太平洋炭を基炭としたも のは $10^{\circ} \mathrm{C} / \mathrm{min}$ までは強度の変化があまりないようで ある。このことは熱可塑性が低い炭種ほどある程度急 熱することが望ましく，そして奔別基炭の場合は前者 より加熱速度の影響が大きいといいうる。また一般的 にはたとえわずかでも粘着性を有する奔別炭を基炭と した場合の方が強度も高、傾向を示す。

（5）成形炭の見掛比重とコークス強度 成形炭の強度は成形炭の見掛比重と正相関にあり, 見掛比重から強度が推定できることを前報において述 ベた。そこで成形炭の見掛比重とコークス強度との関 係を求めてみた。

Fig. 7 は太平洋炭を基炭とした場合の結果を, 配合 および揮発分別にプロットしたものである。

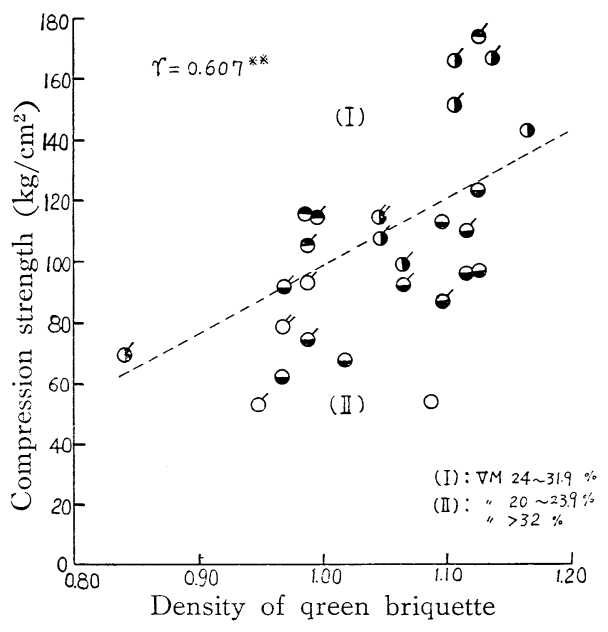

Fig. 7 Relation between density of green briquettes and compression strength of carbonised briquettes

両者の関係はややバラッキがあるが高度の相関があ り, 成形炭強度が大きいものほどコークス化後の強度 も大きい。さらにこれを揮発分でみると（図中鎖線は 揮発分による分割線）同一見掛比重のものでも (I ) に属するもの（VM 24３1.9\%）は（II）に属するも の $(\mathrm{VM}<23.9 \% ，>32 \%)$ 上り強度が大きいことが わかる。すなわち成形炭の残留揮発分は成形密度より 顕著にコークス強度を支配することが認められる。

（6）コークスの収縮率

コークス化過程における收縮率は成形炭の揮発分が 少なく，圧縮密度および粘着炭の配合割合が増すほど 一般に小さくなるが，さらに乾留の加熱速度によつて も異なり, 加熱速度が大きくなるほど小さくなる傾向 がある。

Fig. 8 は奔別炭に夕張炭を $20 \%$ 配合し，揮発分が

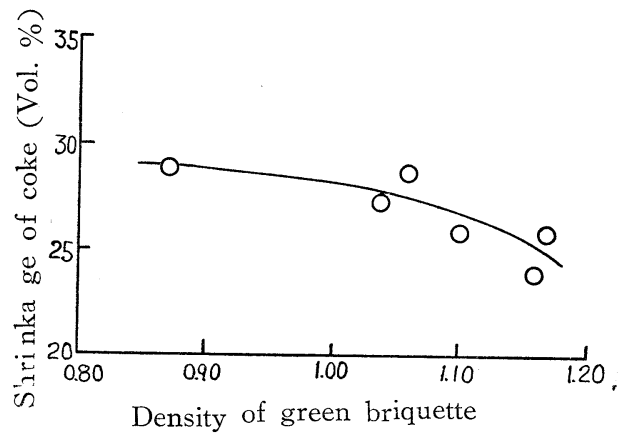

Fig. 8 Relation between density of green briquettes and shrinkage of briquettes during carbonisation 
27 30\% になる温度で加熱, 成形したものを $2.5^{\circ} \mathrm{C} /$

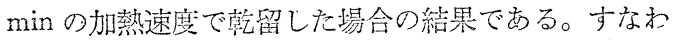
ち収縮率 (容量) 注見捗比重が大なるほぞ小さくなる ことがわかり，1.10の成彩炭の場合（酎圧強度 $160 \mathrm{~kg}$ $/ \mathrm{cm}^{2}$ のものが得られる) $27 \%$ 积度の容積収縮がある。

線收縮率恒方性があり，压繀方向に平行方向では 垂直方向より 0.5 1.5\% ほど小さい。平行方向の 線收縮率は上記の見掛比重で $8 \%$ という結果が得られ た。

\section{IV．中間裝置成形炭の雪気炉による乾留}

上述のように実験室装置による乾留試験を種々の成 形および乾留条件で行なつて成形炭の性状とコークス の耐圧強度との関係について一応の検討を行なつた。

しかし中間装置による成形炭の製造条件は実験室の 場合とは少し異なつている。たとえば実験室において の流動加熱ブスは空気を用い，成形にはプランジャ一 式油圧機が使用されているが，中間装置では都市ガス の然㭠ガスで流動し，成形はダブル・ロール成形機を 用いるなど，当然その成形崖の性状も多少異なること も予想される。

そこで中間装置による連続乾留試験に先だち生成成 形炭を実験室における電気炉によつて, 装入温度, 加
熱率，成形孷温度などについて実験室試䍄の再検的試 験定行なつてコークスの強度との関係を検討した。

1. 試料扔よび乾留条件

成形崖笠造のた加に用いた試料炭は，すべて前報の 場合と同一のもので非粘結炭として太平洋炭，微粘結 炭として奔別炭，配合用弱粘結炭として夕張炭を用い た。

乾留用電気炉は JIS 小形レトルト法によるコークス 化性測定用の電気炉 (内法 $200 \times 200 \times 350 \mathrm{~mm}$ ) および レトルト $(150 \mathrm{~mm} \phi \times 200 \mathrm{~mm})$ を用いた。このレトル 卜に成形炭を約 2 2.5kg (約 100 コ) 採り, 装入温度, 加熱率など乾留条件をいろいる変えて, 最終温度 800 ${ }^{\circ} \mathrm{C}$ まで乾留した。

コークス強度も耐圧強度でなく、すべて JISドラム 試験法に準じた径 $1.5 \mathrm{~m}$ のドラムによる 30 回転の 15 $\mathrm{mm}$ 指数を求めた。

（1）冷却装入乾留 まず冷却成形炭，すなわ台 加熱成形したものを室温まで放置冷却した成形炭で， その結果を Table 1 亿示す。結果は実験室試験と同 様で，スタート炉温を室温, $400,500^{\circ} \mathrm{C}$, 加熱率を 2 , $5,10,20^{\circ} \mathrm{C} / \mathrm{min}$ などの各条件で乾留したが比較的 良好なものでも強度は60位と低いものである。

\section{Table 1 Results of experimental carbonising tests on briquettes} (charged after being cooled)

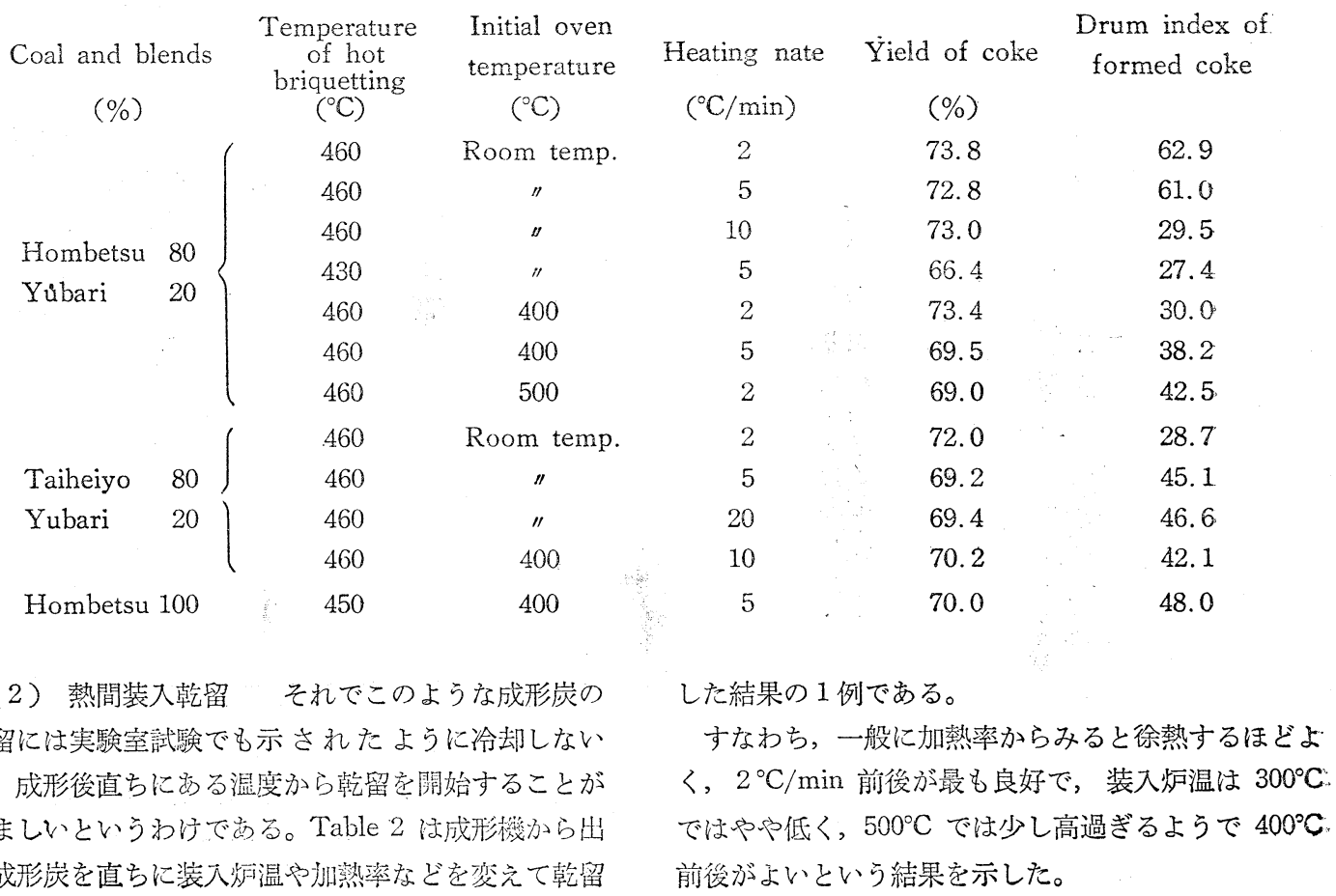


Table 2 Results of experimental carbonising tests on briquettes

\begin{tabular}{|c|c|c|c|c|c|c|}
\hline \multicolumn{2}{|c|}{ Coal and blends } & \multirow{2}{*}{$\begin{array}{c}\text { Temperature } \\
\text { of hot } \\
\text { briquetting } \\
\left({ }^{\circ} \mathrm{C}\right)\end{array}$} & \multirow{2}{*}{$\begin{array}{l}\text { Initial oven } \\
\text { temperature } \\
\left({ }^{\circ} \mathrm{C}\right)\end{array}$} & \multicolumn{2}{|c|}{$\begin{array}{c}\text { Drum index of formed coke, } \\
\text { by heating rate }\end{array}$} & \multirow{2}{*}{$\frac{\text { classified }}{\left(\begin{array}{c}8 \sim 10 \\
\left({ }^{\circ} \mathrm{C} / \mathrm{min}\right)\end{array}\right.}$} \\
\hline (\%) & & & & $\left(\frac{2}{}(\mathrm{C} / \mathrm{min})\right.$ & $\left({ }^{\circ} \mathrm{C} / \mathrm{min}\right)$ & \\
\hline \multirow{5}{*}{$\begin{array}{l}\text { Hombetsu } \\
\text { Yubari }\end{array}$} & \multirow{5}{*}{$\begin{array}{l}80 \\
20\end{array}$} & 460 & 350 & 92.5 & 80.5 & 74.0 \\
\hline & & 460 & 400 & 90.8 & 85.2 & 71.3 \\
\hline & & 450 & 400 & 89.9 & 73.4 & 68.8 \\
\hline & & 420 & 400 & 90.1 & 77.7 & 72.8 \\
\hline & & 460 & 500 & 88.4 & 72.5 & 68.3 \\
\hline Hombetsu & 95 & 450 & 400 & 88.3 & 756 & 668 \\
\hline Yubari & 5 & 400 & 400 & 00.0 & 10.0 & 00.0 \\
\hline \multirow{3}{*}{$\begin{array}{l}\text { Taiheiyo } \\
\text { Yubari }\end{array}$} & \multirow{3}{*}{$\begin{array}{l}80 \\
20\end{array}$} & 450 & 400 & 87.1 & 70.5 & 68.7 \\
\hline & & 450 & 500 & 86.4 & 64.5 & 57.3 \\
\hline & & 450 & 600 & 76.1 & - & 51.5 \\
\hline \multicolumn{2}{|c|}{ Hombetsu 100} & 450 & 400 & 87.4 & 73.2 & 69.3 \\
\hline
\end{tabular}

この理由については多くの複雑な因子がからみあつ ていて明快な説明はできないが，要するに成形炭は加 熱によつて生じた熱可塑性を利用して高圧で成形され るので，その時点では多くの歪をもつたものである。 これを泠却すると固化, 収縮が起り, その歪注矯正さ れることもなく，むしろ大となり亀裂なども生じてく る。そしてつぎの乾留の加熱によつても，もともと少 ない粘着性はすでに失なわれているので融着も行なわ れないし,また個々の成形炭の表面部と中心部の温度 差も大きい状態で加熱されるので乾留過程での亀裂の 発生, 成長が助長される。しかし成形温度附近から直 ちに，乙かも徐熱で加熱を開始すれば成形時の歪もそ の間の可塑性の持続によつて, ある程度矯正されるし 成形炭は均一的に加熱されるので収縮の歪も生ぜず締 まつたコークスを生ずるということである。

そこでさらに成形炭の流動加熱温度との関係を明ら かにするため各温度で作られた成形炭について $5^{\circ} \mathrm{C}$ よび $2^{\circ} \mathrm{C} / \mathrm{min}$ の加熱率で乾留した場合のコークス強 度との関倸を示したのが Fig. 9 および Fig. 10 であ る。

すなわち奔別炭を基炭とした場合は加熱率 $5^{\circ} \mathrm{C} / \mathrm{min}$ で強度 85 前後, $2^{\circ} \mathrm{C} / \mathrm{min}$ では 90 以上のコークスが得 られる。

また Fig. 9 および Fig. 10 の各成形炭の揮発分を 測定してコークス強度との関係を図示すると Fig. 11 および Fig. 12 となる。この傾向は強度測定法の差は あるが実験室結果の揮発分と耐圧強度との関係 (Fig. 3)の場合とほとんど同様である。ただ比較的良好な

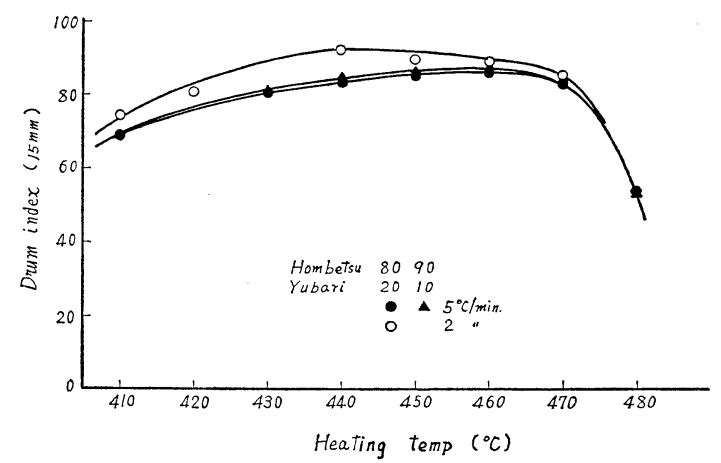

Fig. 9 Relation between temperature to which fine coals to be briquetted are heated in fluidized bed and drum index of carbonised briquettes

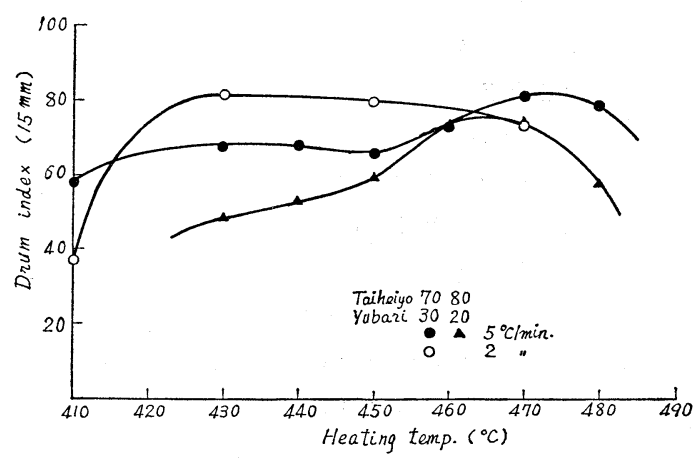

Fig. 10 Relation between temperature to which fine coals to be briquettes are heated in fluidized and drum index of carbonised briquettes 


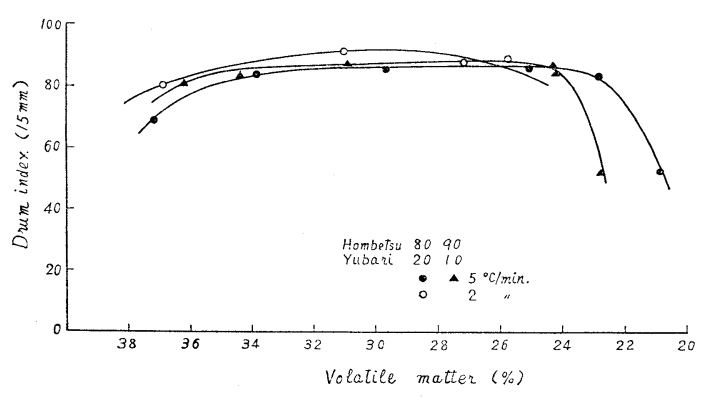

Fig. 11 Relation between volatile matter content of green briquettes and drum index of carbonised briquettes

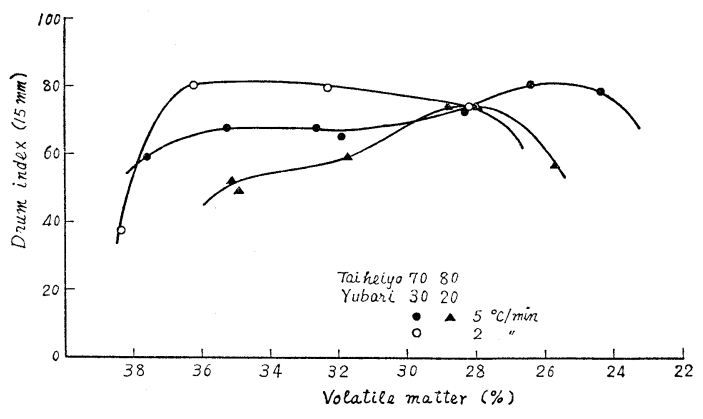

Fig. 12 Relation between volatile matter content of green briquettes and drum index of carbonised briquettes

強度を有するコークスを得るための揮発分量の範囲が 実験室の場合よりわずかではあるが広くなるようで， これはさきにも述べたように流動加熱ガスに実験室で は予熱空気を用いるのでやや酸化を助長し中間装置で は都市ガスの燃焼ガスを用いるので酸化をも比較的少 ない状態で成形されるためと思われる。

とにかく, これらの結果から基炭の種類, 配合割合 などによる各種成形炭の加熱温度あるいは揮発分量と 最適乾留条件との関係が推定できる。

要するに乾留条件としては成形炭の温度附近から乾 留を開始し, $400 \sim 600^{\circ} \mathrm{C}$ 間のいわゆる熔融, 分解の 激しい温度範囲はなるべく徐熱で行なうということで あり，それ以後の加熱は比較的急熱してもコークス強 度には大きな影響はない。

\section{$\mathrm{V}$ ．中間装置による連続乾留}

実験室試験および電気炉乾留試験で成形炭の性状と 最適乾留条件との関係をほぼ明らかとしたので, これ を参考として中間装置による連続乾留試験を行なつ た。

装置の大要は前報にも示したが乾留装置の構造は Fig. 13 に示すような移床式炉で，その仕様はつぎの

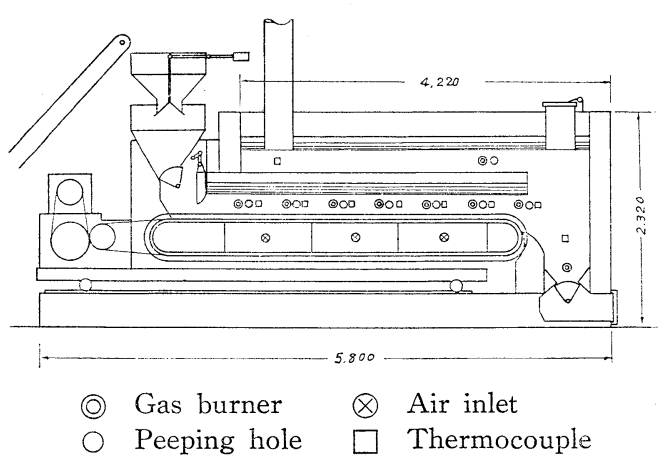

Fig. 13 Details of travelling grate carboniser

ようである。

処理量 : $150 \sim 200 \mathrm{~kg} / \mathrm{hr}$

移動床: 巾 $600 \mathrm{~mm}$, 有効長 $3,000 \mathrm{~mm}$, 軟鋼 (ア ルマ加工)

変速機 : $1.5 \mathrm{kw}, 2 \sim 20 \mathrm{~m} / \mathrm{hr}$

装入ゲード : 0 200mm

加熱用バーナー：片側 9 本 計 18本

送排送機: 加熱ガス用, 燃燒空気用, 冷却用各 1 台 各バーナーに点火して徐々に炉内各部を所定の温度 に上昇して（装入口部分を大体 $400^{\circ} \mathrm{C}$ ，移床末端部が $700^{\circ} \mathrm{C}$ 前後となるような温度勾配とする）装入を開始 する。成形炭は順次高温部に送られ, 乾留ガスが発生 寸るにしたがつて, 各バーナーからの加熱用ガスを絞 り，同時に空気量を調節して発生ガスの燃燒のみによ つて乾留を続ける。火床末端部から最後の熟成室に溜 つて, ここで $800 \sim 900^{\circ} \mathrm{C}$ 位まで加熱されて取出し散 水消火する。

火床で高温乾留しょうとするとその材質は耐熱鋼で つくるようになり，炉が高価になるとともに徐熱と温 度勾配を維持する関係からその長さももつと長くする 必要がある, そのため火床部分ではなるべく低温乾留 し熟成室で高温乾留するようにしたものである。 なお昇温化要する時間は使用ガス量約 $20 \mathrm{~m}^{3} / \mathrm{hr}$ で 20 時間前後で芹定の温度としている。

以上の要領で行なつた連続試験の結果の 1 例が Tadle 3 である。

ただし装入ゲートの開度は約 $50 \mathrm{~mm}$ で, 成形炭 $2 \sim 3$ コの厚さで行なつた。火床下部からの送風は全然行な わず, 炉内圧は煙突のダンパーによつて調節し煙突直 下で $-1 \sim-2 \mathrm{~mm}$ (水柱) で乾留帯ではほぼ 0 であ る。また取出しは熟成室に 10 15 kg 位溜るごとに行 なつたもので, 熟成室に先に落ちたものと取出直前に 落ちたものには揮発分量にやや差がある。 
Table 3 Results of carbonisation of hot briquettes with pilot carboniser

\begin{tabular}{|c|c|c|c|c|c|c|c|c|c|}
\hline \multirow{2}{*}{\multicolumn{2}{|c|}{$\begin{array}{l}\text { Blends used in } \\
\text { hot briquetting } \\
(\%)\end{array}$}} & \multirow{2}{*}{$\begin{array}{l}\text { Tempera- } \\
\text { ture of hot } \\
\text { briquetting } \\
\qquad\left({ }^{\circ} \mathrm{C}\right)\end{array}$} & \multirow{2}{*}{$\begin{array}{c}\text { V. M. } \\
\text { of } \\
\text { briquette } \\
(\%)\end{array}$} & \multirow{2}{*}{$\begin{array}{l}\text { Speed of } \\
\text { travelling } \\
\text { grate } \\
(\mathrm{m} / \mathrm{hr})\end{array}$} & \multicolumn{5}{|c|}{ Coke } \\
\hline & & & & & $\begin{array}{l}\text { Yield } \\
(\%)\end{array}$ & $\begin{array}{r}\text { V. M. } \\
(\%)\end{array}$ & $\begin{array}{l}\text { Ash } \\
(\%)\end{array}$ & $\begin{array}{l}\text { Drum } \\
\text { index } \\
(15 \mathrm{~mm})\end{array}$ & $\begin{array}{c}\text { Trommel } \\
\text { index } \\
(15 \mathrm{~mm})\end{array}$ \\
\hline \multirow{3}{*}{$\begin{array}{l}\text { Hombetsu } \\
\text { Yubari }\end{array}$} & \multirow{3}{*}{$\begin{array}{l}80 \\
20\end{array}$} & 450 & 30.1 & 2 & 58.5 & 3.5 & 15.7 & 78.5 & 91.8 \\
\hline & & 460 & 28.2 & 3 & 60.8 & 4.0 & 15.4 & 80.3 & 93.3 \\
\hline & & 470 & 25.0 & 3 & 64.7 & 3.2 & 15.3 & 75.5 & 92.9 \\
\hline \multirow{3}{*}{$\begin{array}{l}\text { Hombetsu } \\
\text { Yubari }\end{array}$} & \multirow{3}{*}{$\begin{array}{l}90 \\
10\end{array}$} & 450 & 29.5 & 2 & 53.3 & 3.8 & 16.0 & 73.3 & 88.5 \\
\hline & & 460 & 26.7 & 2 & 56.6 & 5.4 & 16.3 & 70.9 & 91.0 \\
\hline & & 470 & 24.8 & 3 & 65.1 & 5.3 & 15.8 & 76.4 & 94.0 \\
\hline \multirow{3}{*}{$\begin{array}{l}\text { Taiheiyo } \\
\text { Yubari }\end{array}$} & \multirow{3}{*}{$\begin{array}{l}70 \\
30\end{array}$} & 450 & 30.0 & 3 & 60.3 & 6.8 & 17.2 & 68.8 & 88.6 \\
\hline & & 460 & 26.5 & 3 & 66.6 & 4.6 & 16.4 & 73.0 & 89.3 \\
\hline & & 470 & 24.1 & 3 & 64.8 & 3.3 & 16.6 & 75.9 & 90.8 \\
\hline Taiheiyo & 80 & 460 & 27.0 & 3 & 68.7 & 8.6 & 16.8 & 69.5 & 88.1 \\
\hline Yubari & 20 & & & & & & & & 00.1 \\
\hline
\end{tabular}

Table 3 の結果のコークス強度をみると，比較的よ いものでも $15 \mathrm{~mm}$ 指数で約 80 位で, 電気炉の場合に 比べると大体10前後低い結果を示している。

この原因についてはいろいろ考えられるが，まず成 形炭については加熱方式がバッチのため成形機への装 入も断続で, その前後の成形炭には当然不完全なもの もできて，これらも一応装入されている。（電気炉試 験の場合は成形過程で比較的中間の均一な成形炭を採 取した)。さらに乾留過程では (1) 炉内の温度測定が 加熱焰に影響されたり, 連続乾留を行なつている炉内 の対流, 装入の断続などによつて温度調整が適正に行 なわれていなかつた。(2) 移床速度を最低の $2 \mathrm{~m} / \mathrm{hr}$ と しても火床上の滞留時間は $90 \mathrm{~min}$ で, 未端温度 $700^{\circ} \mathrm{C}$ とすれば加熱率は約 $3.3^{\circ} \mathrm{C} / \mathrm{min}$, 未端温度は $700^{\circ} \mathrm{C}$ 以上となり易いので加熱率もさらに大となる。移床速 度 $3 \mathrm{~m} / \mathrm{hr}$ では $5^{\circ} \mathrm{C} / \mathrm{min}$ 以上である。(3) 乾留炉は 一応気密構造となつているが多少空気の吸込みがあり 酸化などのコークス化性への影響があるのではない か。(4) その他装入過程での成形機からコンベヤ一, ホッパー，装入口までの間の成形炭の温度降下，この 間内での落下衝撃などが考えられる。しかし最近にお いては装置の改造, 補修, 操作の熟練などで成形炭も 順次均一なものが生成されるようになり, 乾留炉にお いても，たとえば乾留帯の中間 2 力所に熱遮へい板を 設けて炉内温度勾配安調整するとか, 特に重要な装入 口部の温度は移動床の下面も測定し加熱率を調節する とか, 種々対策を考えつつ試験を進めたためコークス 強度も順次向上しつつある。

本法によるコークスの性状は, Table 3 によると揮

発分，灰分は一般コークスのそれに比すればいずれも やや多い，しかしこれらは原料炭の処理，䀧択および 乾留操作によつていずれも低下しらる。

見掛比重 $1.1 \sim 1.3$, 気孔率は $30 \sim 40$ 前後で, 一般 コークスに比してやや緻密である。また非粘結炭ある いは微粘結炭を主原料とする関係上，反応性は良好で ほぼ木炭に近い值 (JIS 法) を示す。この点昔時の治 金には木炭が使用されていたとはいえ，現代の大型化 した高炉に対しての影響については今後の検討にまた ねばならない。

\section{VI. む び}

国内炭からの成形コークス製造試験に関し, 第 2 報 として加熱成形炭の乾留について, 実験室試験, 電気 炉試験などから成形炭の性状と乾留条件との関係を明 らかにし，ついで中間規模の連続試験装置について装 置の大要と試験結果について述べ, ほぼ期待に近い成 形コークスを製造しうるようになつたことを報告し た。

また以上一連の試験結果からは流動加熱成形炭の製 造法において, 現在のバッチ式から連続化も容易に可 能との自信を得, 目下連続式流動加熱成形装置の建設 を計画している。

終りに本研究について種々御指導を戴いた石炭部長 本田英昌博士, 実験に協力された木村英雄博士, 加藤 勉技官に深く謝意を表する。

\section{文献}

1）吉田・他，燃協誌，45，575

2）第41回コークス特別会講演 


\title{
Manufacture of Formed Coke by Hot-Briquetting Method (II) Carbonisation of Briquettes
}

\author{
by Yuji Yoshida, Junjiro Kumai, Kiyoshi Yamaguchi, \\ Minoru Shiraishi, Yuzo Toda \& Katsuhisa Maruyama \\ (Resourcs Rcscarch Institute)
}

SYNOPSIS:--In order to develop a new process to make metallurgical coke from the blends mainly composed of non-or slightly caking, high volatile coals, hot briquetting followed by corbonisation has been carried out on a pilot scale.

This paper deals with the carbonisation of hot briquettes, of which manufacture was reported previously and given here some additional explanations.

The preliminary small scale tests on carbonising briquettes to seek the suitable conditions for obtaining hard fomed coke showed that the hot briquettes should be: 1) $24 \sim 32$ per cent in volatile matter, 2) charged immediately into the oven without being cooled, 3) carbonised as slow as possible, until the temperature reaches about $600 \sim 700^{\circ} \mathrm{C}$.

Based on these results, a pilot carboniser of travelling grate type with a capacity of $100 \mathrm{~kg} / \mathrm{hr}$ was constructed. The hot briquettes were carbonised to about $600 \sim 700^{\circ} \mathrm{C}$ in $1.5 \sim 2 \mathrm{hr}$ on the travelling grate, which is made of mild steel and $600 \mathrm{~mm}$ wide, 3,000 $\mathrm{mm}$ long. Then, semi-carbonised briquettes were turned into the high temperature chamber, where they were rapidly carbonised to about $900^{\circ} \mathrm{C}$. Heat required is supplied by combustion of the gas evolved from the briquettes.

The resulting formed coke has the drum index of $80 \%$ which is lower by $10 \%$ than that obtained by a small scale test. 